where $f$ is the whole map-distance between the two intervals, $\mathrm{ft}_{r}$ is the map-distance on the right segment from the boundary; $a=0.257=a_{e}, b=0.559$ (Fig. 2). The limits of the validity of this equation can be discussed only when suitable experimental data are available.

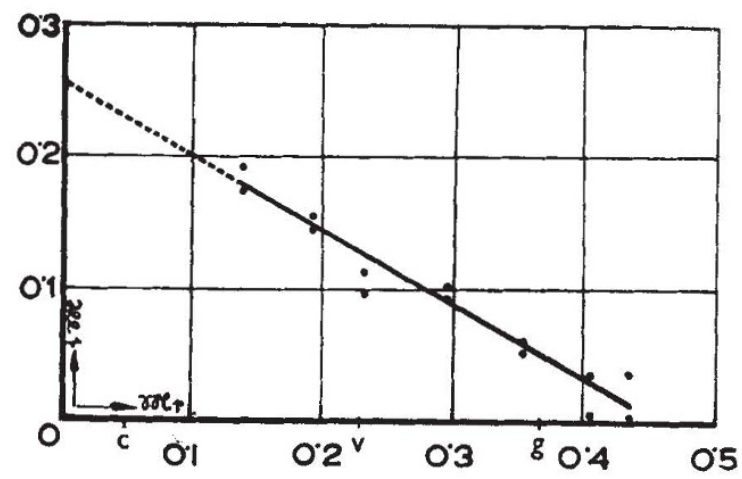

Fig. 2.

TranstTive INTERference. ABscissa: PRIMary MAP OF THE RIGHT SEGMENT ; 0 POINT $=$ MIDDLE OF THE INTERVAL CV C.

The three constants $a_{e}, a_{r}, b$ make it possible to compute from six f-values between neighbour genes, which stand for the six observed $f$-values-that is, from the loci of the seven genes on the primary map-all $21 \mathrm{f}$-values, the average deviation being 0.6 per cent with a maximum of 1.8 per cent (Table 1 ).

Table 1. f-Valdes OF the "XPLE" Expertment.

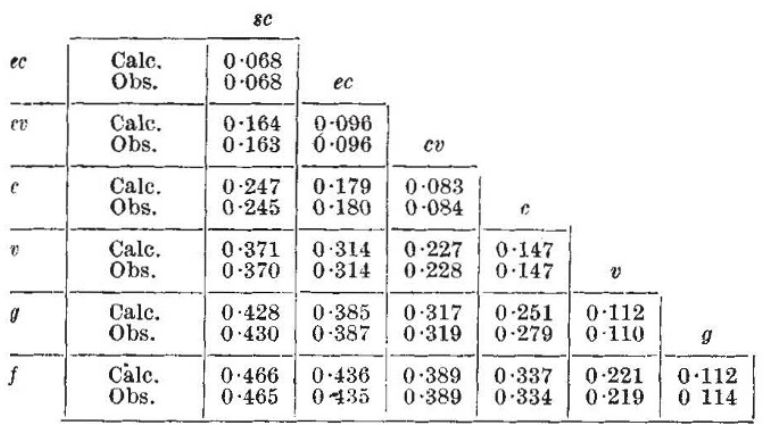

The left segment was calculated on the basis of the simplifying assumption $i=1$. Using Morgan's terminology, the two equations represent the relation between frequency of crossing-over and frequency of recombination?

K. DE K KRösY.

Institute of Physiology,

University of Budapest. July 1.

${ }^{1}$ v. Kőrsöy, K., "Versuch einer Theorie der Genkoppelung”' (Berlin, 1929).

'Bridges, C. B., and Olbrycht, T. M., Genetics, 11, 41 (1926).

s v. Körösy, K., Naturwiss., 20, 324 (1932).

‘Dobzhansky, Th., Biol. Zentralbl., 52, 493 (1932).

'Bridges, C. B., Biol. Zentralbl., 47, 600 (1927).

- Stern, C., “Handb. der Vererbungswiss.”, 1, H. 125 (Berlin, 1933)

'Morgan, T. H., Bridges, C. B., and Sturtevant, A. H., "Bibliograph. genet.", 2, 99 (1925).

\section{Raman Spectra of Deuteroethylenes}

Thw various deuteroethylenes can be obtained by exchange from ethylenes and deuterium oxide on a nickel catalyst. $15 \mathrm{gm}$. of heavy water $\left(\mathrm{D}_{2} \mathrm{O}\right)$ and 6 litres of ethylenes (N.T.P.) yielded after an exchange of several days at $150^{\circ} \mathrm{C}$. a mixture of ethylenes containing about 50 per cent of the hydrogen as deuterium. The Raman spectrum of this substance was taken. In order to identify the lines and attribute them unambiguously to the different compounds, some of the deuteroethylenes have been prepared in a pure state. The ethylene $\mathrm{C}_{2} \mathrm{D}_{4}$ was obtained in the following way:

$$
\begin{aligned}
& \mathrm{C}_{2} \mathrm{D}_{2}+2 \mathrm{DBr} \rightarrow \mathrm{C}_{2} \mathrm{D}_{4} \mathrm{Br}_{2} ; \\
& \mathrm{C}_{2} \mathrm{D}_{4} \mathrm{Br}_{2}+\mathrm{Zn}=\mathrm{C}_{2} \mathrm{D}_{4}+\mathrm{ZnBr}_{2} .
\end{aligned}
$$

The compound so obtained contained about 10 per cent $\mathrm{C}_{2} \mathrm{D}_{3} \mathrm{H}$; its $\mathrm{D}$ content was thus about 97 per cent of the total hydrogen. The cis and trans dideuteroethylenes were obtained in an analogous way starting from $\mathrm{C}_{2} \mathrm{D}_{2}$ and $\mathrm{HBr}$. The comparison of the various spectra permits the classification of the lines as shown in the accompanying table:

\begin{tabular}{|c|r|r|r|r|r|}
\hline $\mathrm{C}_{3} \mathrm{H}_{4}$ & $\mathrm{C}_{2} \mathrm{D}_{4}$ & $\mathrm{C}_{2} \mathrm{H}_{8} \mathrm{D}_{2}$ & $\mathrm{C}_{2} \mathrm{HD}_{3}$ & $\begin{array}{r}\mathrm{C}_{2} \mathrm{H}_{2} \mathrm{D}_{2} \\
\text { cis and } \text { trans }\end{array}$ & $\begin{array}{c}\mathrm{C}_{2} \mathrm{H}_{2} \mathrm{D}_{2} \\
\text { asym. }\end{array}$ \\
\hline 1621 & 1515 & 1600 & 1545 & 1567 & 1581 \\
3007 & 2251 & 3016 & 2272 & 2276 & 2221 \\
1341 & 981 & 1397 & 996 & 2290 & \\
3082 & 2304 & 3104 & & 1282 & 1379 \\
& & 1285 & & 1214 & \\
& & 2266 & 2215 & 3033 & \\
& & 2965 & & 3046 & \\
& & & & 863 & \\
\hline
\end{tabular}

$\left(\mathrm{cm} .^{-1}\right)$.

There is a slight discrepancy between the experimental results and the theoretical calculations carried out by Manneback and Verleisen. The potential function proposed by these authors has thus to be revised; this revision has been started by Manneback and his co-workers. The comparison of the first three lines $\left(S_{1}\right.$ lines) of $\mathrm{C}_{2} \mathrm{H}_{4}$ and $\mathrm{C}_{2} \mathrm{D}_{4}$ gives a measure of the anharmonicity correction. The ratio of the product of these three frequencies should be 2. Deviations from this value are to be ascribed to the anharmonicity of the vibration. This constant was not taken into account in the earlier calculations ; in fact, we find the value :

$$
\frac{1621 \times 3007 \times 1341}{1515 \times 2251 \times 981}=1.954 .
$$

The results indicate that it is of the order of magnitude of 2 per cent. Several lines not given in the table could be detected in the spectrum of the dideuteroethylenes. It has not been possible to ascribe them unambiguously. Further work is in progress.

M. DE HemptinNe.

J. JUNGERS.

J. Delfosse.

Physical Laboratory,

University,

Louvain.

July 13 